\title{
O TERCEIRO SETOR: SISTEMATIZAÇÃO NORMATIVA A PARTIR DA SOCIEDADE CIVIL
}

\author{
BRUNO VALVERDE CHAHAIRA
}

\begin{abstract}
RESUMO - A partir da década de 90 do século XX mais se ampliou o espaço da sociedade civil, crescendo o número de entidades associações que passaram a ser conhecidas sob o nome de Organizações Não Governamentais (ONGs) ou sob a denominação de Terceiro Setor. Em virtude do florescimento em alto grau e das atuações dessas entidades, o Estado pluralista, Estado de associações, Estado de organizações, com reflexos do convívio entre o Estado e as entidades do terceiro setor incidindo sobre a tradicional dicotomia público e privado, para se cogitar não mais uma separação rígida, mas a busca de critérios de coexistência. Destacando-se da mesma forma, os vínculos com o Estado as entidades do terceiro setor atuam de formas diversas, por exemplo: exercem pressões na busca de realização dos interesses que defendem, têm assento em órgãos públicos deliberativos ou consultivos, participam de audiências e consultas públicas, organizam manifestações públicas, bem como o destaque da atuação das empresas além da atividade das indústrias e do comércio de produtos e serviços, vem crescendo e chamando a atenção de todos. Sob o nome de responsabilidade social empresas patrocinam, por exemplo, atividades culturais, esportivas, sociais, educacionais, muitas vezes em colaboração com o poder público. Eis mais um aspecto da aproximação entre público e privado.
\end{abstract}

PALAVRAS-CHAVE - Terceiro Setor. ONGs.OSCIP. Sociedade civil. Direito público.

\section{INTRODUÇÃO}

As últimas décadas desfizeram mitos e ilusões. O mundo viveu a transformação do mundo socialista ao Estado $\mathrm{Ne}$ oliberal numa velocidade alucinante. O Estado passou a faltar em algumas necessidades básicas dos cidadãos. Isto determinou que prospecções inspiradas em teorias sociais generosas perdessem força, como as Teorias Socialistas de Karl Marx, por exemplo, em que Estado seria o grande provedor das necessidades básicas da população. Contudo, com o passar dos anos, a realidade não foi exatamente como previam tais teorias e exigiram ágeis readaptações político-administrativas por parte do Estado. Isso fez com que sociedade civil se organizasse cada vez mais e ganhasse força frente a fragilidade do Estado em suprir as necessidades básicas de sua população. Surge então oficialmente o chamado Terceiro Setor. O Terceiro Setor no Brasil não é uma realidade nova nem tampouco importante. Ele abrange as Organizações Não Governamentais, Organizações Sociais, Organização da Sociedade Civil de Interesse Público (OSCIP’s), Fundações, Institutos Empresariais, Associações Comunitárias, Instituições Filantrópicas e outras. Ainda que seja precária e bastante recente a consciência que atribui unidade e um sentido relativamente homogêneo às práticas que as abordagens tradicionais identificavam exclusivamente à filantropia ou à solidariedade cívica, o terceiro setor se tor- nou nos dias de hoje, peça fundamental no desenvolvimento da sociedade mundial, preenchendo as lacunas deixadas pelo poder público. Empresas, Igrejas, entidades das mais diversas atuações investem, há décadas, em iniciativas cujo impacto social está longe de ser insignificante, mesmo tendo sido quase sempre desprezadas. Para usar uma fórmula caricata e grosseira, mas didaticamente útil, a própria sobrevivência de amplas camadas da sociedade brasileira parece inexplicável, quando se lêem os dados relativos à renda e sua absurda distribuição. É importante destacar que laços e canais invisíveis se estabeleceram e se consolidaram ao longo dos anos, o que propiciou a existência de fluxos de recursos dos mais diferentes tipos, em diversas esferas da população. Isto criou condições mais humanas e suportáveis para muitos grupos marginalizados e redefiniu o pacto social por reinvestir na sociabilidade.

Atualmente no Brasil admite-se que as organizações do Terceiro Setor podem ser parceiras eficazes na execução das políticas sociais. Mais do que isso, reconhece-se que esse setor cumpre um papel social importante e que, por isso, deve ser incentivado e apoiado para que possa crescer e melhorar seu desempenho, atendendo assim as necessidades das camadas sociais mais necessitadas.

A partir da década de 90, a sociedade ingressou $\mathrm{em}$ uma nova realidade que foi nominada de Organizações Não 
Governamentais - ONG - que, até certo tempo atrás eram contestadoras, cobradoras do Poder Público de melhores condições de vida à população e, logo passaram a ser parceiras do Estado, prestando serviços sociais como educação, saúde, assistência social, cultura, entre outros, que antes, na sua maioria eram executados diretamente pelo Estado. O estudo do Terceiro Setor se tornou cada vez mais importante, considerando sua participação cada vez maior na execução de serviços sociais ou não exclusivos. A dissertação terá por objeto a análise das relações de "parceria" entre a Administração Pública e entidades da sociedade civil sem fins lucrativos. Pretende-se neste trabalho definir com clareza o regime jurídico dos vários instrumentos existentes, em face ao ordenamento jurídico pátrio, como os contratos administrativos, convênios, contratos de gestão e termos de parceria, para fins diversos como cooperação, fomento e desburocratização do aparelho estatal. O presente estudo abarcará apenas as transferências diretas ocorridas por meio destes instrumentos firmados com organizações da sociedade civil, normalmente qualificadas com títulos concedidos pelo Poder Público, como por exemplo, a utilidade pública nas esferas municipal, estadual e federal. Antes de se adentrar ao tema do terceiro setor e suas parcerias, far-se-á uma análise do papel do Estado e da Administração Pública, tratando de temas como o Estado social, a democracia e a burocracia do setor público. É nesta realidade social que o presente estudo pretende passar uma visão realista e por muitas vezes de muita indignação com a situação vivida pela sociedade brasileira.

\section{A. AFIRMAÇÃO DO ESTADO E A ADMINISTRAÇÃO PÚBLICA}

O Estado é uma nação política e juridicamente organizada. Uma pessoa jurídica de Direito Público interno, com soberania, composta pelo povo e regida pelo governo, com o seu poder político. A Administração Pública é o aparelho por qual o Estado se utiliza para a consecução dos escopos do governo.

Sobre o Estado, Romeu Felipe BACELLAR FILHO [3] salienta que

não podendo viver isoladamente, o homem constituiu sociedades que tiveram de se organizar internamente para poder sobreviver, nascendo assim o conceito de nação.

Para referido autor o Estado é uma nação politicamente organizada. É um ente composto por seu governo soberano, de um poder de mando originário; é comunidade de homens, com força superior de ação, de mando e de coerção; é pessoa jurídica de Direito Público interno que atua no Direito Público e Privado; juridicamente organizado, é constituído de povo, território e governo; sua vontade manifesta-se por meios de seus Poderes (funções) Executivo, Legislativo e Judiciário, com suas atividades e competências precípuas, mas não necessariamente privativas. Já o governo, para o autor, é o conjunto de Poderes e órgãos constitucionais, o complexo de funções estatais básicas, a condução política dos negócios públicos e sua constante é a sua expressão política de comando, de iniciativa, de fixação de objetivos do Estado e de manutenção da ordem jurídica vigente.

No entanto, para definir Governo é possível utilizar os ensinamentos de Norberto BOBBIO [7], que ressalta,

"Governo é o conjunto de pessoas ou complexo de órgãos que exercem o poder político e que determinam a orientação política de uma determinada sociedade, os governantes são as pessoas que governam o Estado e os governados são aqueles sujeitos ao poder de governo na esfera estatal".

Para o autor, se o Estado surgiu no século XVI, um poder de governo, rudimentar, aparece na passagem da comunidade primitiva para a organização política da sociedade. O governo é o órgão que tem a função de impor as regras de conduta e de tomar as decisões necessárias para manter a coesão do grupo. É uma forma de poder relativamente autônomo em relação aos vários grupos sociais, com a função específica de realizar a integração política da sociedade e a sua defesa no confronto com os grupos externos.

O governo coincide com o Poder Executivo, a Administração Pública executa as decisões do governo, e os órgãos dos Poder Legislativo e Judiciário, mesmo não sendo órgãos de governo, delimitam e controlam suas ações.

Conforme o entendimento do Hely Lopes Meirelles [23], é possível dizer que a Administração Pública é o conjunto de órgãos instituídos para consecução dos objetivos do governo; é o conjunto das funções necessárias aos serviços públicos em geral; é o desempenho perene e sistemático, legal e técnico, dos serviços próprios do Estado ou por ele assumidos em benefício da coletividade; é todo o aparelhamento do Estado preordenado à realização de serviços, visando a satisfação das necessidades coletivas.

Ainda no entendimento de Romeu Felipe Bacellar Filho [3], tem-se com relação Administração Pública que,

"à medida que o Poder Público se organiza, cria um aparelhamento complexo para cuidar de seus serviços e dar consecução aos seus objetivos". O autor ainda ensina que "a Administração Pública, considerada um aparelhamento constituído pelo Estado para satisfazer o bem comum, deve ter realçada, em sua atuação, a compreensão de que o Estado é uma síntese de todos". Conclui que "a existência da Administração Pública só tem sentido em função de uma justa e equiitativa distribuição, entre os cidadãos, dos direitos e os encargos sociais".

A Administração Pública é vista como um conjunto de disposições e intervenções mediante as quais o Estado e outras entidades públicas buscam, dentro dos rumos gerais traçados pela Política.

A principal finalidade esta direcionada a coordenação e orientação das atividades privadas assegurando sempre a satisfação regular das necessidades de bem-estar dos indivíduos, obtendo e empregando racionalmente para esse efeito 
os recursos possíveis e adequados para sempre atingir o êxito esperado pela sociedade.

Ainda se pode definir como,

"um sistema de órgãos hierarquizados ou coordenados a que está atribuída a promoção e realização dos interesses coletivos por iniciativa própria, para execução de preceitos jurídicos ou por imposição do bem comum, e utilizando todas as técnicas adequadas à obtenção dos resultados visados, podendo também praticar atos jurisdicionais relacionados com sua atividade funcional" [3].

Para falar de Estado social se faz necessária a busca pelos conhecimentos do sociólogo português Boaventura de Souza Santos, que retrata a reforma do Estado, demonstrando dois paradigmas de transformação social da modernidade, sendo o primeiro a grande revolução, contra o Estado, e o segundo o reformismo, realizado pelo Estado.

O Estado é o grande causador dos problemas, pois a população cresceu de maneira desenfreada e o mesmo não conseguiu suportar a demanda, deixando de prover as necessidades básicas de seu povo,por isso, vem a ser o foco principal da atuação da reforma, fazendo surgir a grande crise do reformismo. Esse momento chamado de reformismo, destacou o Estado como se ele fosse uma grande "arena política" onde o capitalismo buscou cumprir todas as suas potencialidades por via do reconhecimento dos seus limites. A forma política mais acabada do reformismo foi o Estado-Providência nos países centrais do sistema mundial, com Inglaterra, Áustria e Alemanha, onde a tradição social democrata tem fortes raízes e o Estado desenvolvimentista nos países semiperiféricos e periféricos, como o Brasil.

Para Boavetura de Souza Santos,

Enquanto mudança social normal, o reformismo não é pensável sem o contraponto da mudança social anormal, ou seja, da revolução. Aliás, o mesmo vale para a revolução. A análise das grandes revoluções modernas mostra que todas elas recorrem ao reformismo como condição do seu êxito e consolidação. De fato, uma vez ocorrida a ruptura revolucionária, as primeiras medidas dos novos poderes foram invariavelmente as de se protegerem contra a eclosão de novas revoluções para o que recorreram à lógica reformista da repetição e melhoria. retrospectivamente, pois, as revoluções têm sido sempre o momento inaugural do reformismo enquanto o reformismo só faz sentido político enquanto Processo pós-revolucionário. Mesmo quando o seu objetivo é prevenir a eclosão da revolução, a sua lógica opera por antecipação da situação pós-revolucionária.

A realidade é que com o fim do reformismo se inicia o movimento para a reforma do Estado, tendo como grande fase inicial a figura do Estado irresponsável, trazendo a idéia de que o Estado era inerentemente ineficaz, parasitário e predador. Por isso a única reforma possível e legítima consiste em reduzir o Estado ao mínimo necessário ao funcionamento do mercado.

A partir deste momento a sociedade brasileira percebe que existiam funções que eram exclusivas do Estado, bem como que existiam funções das que o Estado foi tomando por concorrência de outras instâncias não estatais de regulação social.

Toda a mudança Estatal provocada por esse movimento que impressionou a sociedade global, trouxe assuntos importantes para serem analisados e discutidos dentro de nosso Estado, como, dívida externa, ajustamento estrutural, controle do déficit público e inflação, privatização, desregulamentação, entre outros assuntos que desestruturavam os estados.

\section{1) Terceiro Setor: Evolução e afirmação (O.S E OSCIPS)}

Na perspectiva clássica, o Estado representa uma sociedade política organizada e detentora do poder soberano que lhe atribui força necessária à criação de uma ordem jurídica, dentro dos limites de seu território, e autoriza a imposição dessa ordem ao seu povo. Fazendo uma sucinta análise de cada um dos elementos do Estado, tem-se:

- Soberania representa tanto o respeito geral ao ente criado para organizar politicamente a sociedade, como a força necessária à imposição das decisões dele emanadas, ou seja, a soberania é representada pelo monopólio da força ou da coerção legítima ${ }^{1}$ onde somente o Estado possui legitimidade para criar e impor direitos e deveres por meio de normas aos membros da sociedade que representa;

- O limite material ao exercício do poder estatal é a fronteira, ou seja, o Estado é detentor de poder soberano somente nos limites do seu território, não tendo legitimidade para impor suas decisões fora desses limites; inclusive nos casos de extensão do território, como nos navios, aeronaves, consulados e embaixadas.

- O destinatário das decisões emanadas do poder Estatal é o povo de determinado território, não estando outros povos sujeitos legitimamente à sua força.

Ainda fortalecendo a definição do Estado, Romeu Felipe Bacellar Filho, salienta que

[...] não podendo viver isoladamente, o homem constituiu sociedades que tiveram de se organizar internamente para poder sobreviver, nascendo assim o conceito de nação. O Estado é uma nação politicamente organizada, composto por seu governo soberano. O Estado é a ordem jurídica soberana, que tem por fim o bem comum de um povo situado em determinado território [3].

Diante de todo esse estudo sobre o Estado e suas particularidades, é importante ressaltar que existem diferenças significativas entre o Estado e o Governo.

Hely Lopes Meirelles, faz uma distinção entre o Estado e o Governo, que é importante neste momento destacar:

\footnotetext{
1 "Na teoria pura de Kelsen, a soberania não é um 'poder' como ensina a corrente tradicional, nem tampouco uma 'qualidade do poder', como pretendem especialmente os partidários da escola de Gerber e de Laband, mas representa tão-somente a unidade e a validade de um dado sistema de normas, unidade e validade que são uma decorrência lógica de "norma fundamental hipotética' posta pelo jurista como condição do próprio sistema" [29]
} 
O Estado é a corporação territorial dotada de um poder de mando originário, é comunidade de homens, com potestade superior de ação, de mando e de coerção, é pessoa jurídica de direito público interno, soberana, que atua no Direito público e privado, juridicamente organizado, constituído de povo (componente humano), território (base física) e governo soberano (elemento condutor); e a vontade do Estado manifesta- se por meios de seus Poderes Executivo, Legislativo e Judiciário, com suas funções precípuas, mas não privativas. Já o governo, é o conjunto de Poderes e órgãos constitucionais, é o complexo de funções estatais básicas, é a condução política dos negócios públicos, e sua constante é a sua expressão política de comando, de iniciativa, de fixação de objetivos do Estado e de manutenção da ordem jurídica vigente [23].

Conforme os ensinamentos do Professor Hely Lopes Meirelles é possível visualizar que a formação do governo é vista como um conjugado de pessoas ou complexo de órgãos que utilizam sempre como basilar exercício o poder político, que se justifica com atividades, bem como auxiliando na medida do possível em orientações e é claro prestando toda a assessoria frente ao controle político na sociedade.

No entanto para Norberto Bobbio tem-se que,

[...] se o Estado surgiu no século XVI, um poder de governo, rudimentar, aparece na passagem da comunidade primitiva para a organização política da sociedade. O governo é o órgão que tem a função de impor as regras de conduta e de tomar as decisões necessárias para manter a coesão do grupo, é uma forma de poder relativamente autônomo em relação aos vários grupos sociais, com a função específica de realizar a integração política da sociedade e a sua defesa no confronto com os grupos externos. O governo coincide com o Poder Executivo, a Administração Pública executa as decisões do governo, e os órgãos dos Poder Legislativo e Judiciário, mesmo não sendo órgãos de governo, delimitam e controlam suas ações [7].

Por meio dos ensinamentos de Norberto Bobbio, é possível entender o governo como sendo um órgão que tem a função de impor as regras de conduta e de tomar as decisões necessárias para manter a coesão do grupo, tanto que ele destaca que o governo coincide com o Poder de Executivo, de tomada de decisões, buscando sempre a função específica de realizar a integração política da sociedade e a sua defesa no confronto com os grupos externos.

No entanto, sabe-se que o governo, como bem ressaltou Norberto Bobbio, tem uma forma de poder relativamente autônomo em relação aos vários grupos sociais. Logo, dentro de nossa sociedade se percebe a atuação desses grupos sempre em função dos benefícios sociais, como é o caso das organizações sociais que foram criadas pelo Governo de Fernando Henrique Cardoso, e adotaram o padrão das organizações chamadas "quangos" (quasi non-governamental organizations), do Reino Unido. Logo, as organizações so- ciais são "quase-governamentais", por sua dependência aos recursos públicos, com sua estrutura com membros do Poder Público, e porque até agora resultaram da extinção de entidades públicas, faltando a elas as características de autogoverno e participação voluntária.

Ao falar de autogoverno, deve-se entender um conceito abstrato que pode se referir a diversas escalas de organização, podendo-se utilizar o termo para descrever um povo ou grupo apto a exercer todas as funções necessárias do poder sem influência de qualquer autoridade que eles mesmos não possam alterar.

Sérgio de Andréa Ferreira defende a existência de entidades governamentais e não governamentais, a saber:

Existem as entidades governamentais e não governamentais, sendo que as organizações sociais não são governamentais, não têm vinculação administrativa legal com o Poder Público, mas apenas relação via contrato de gestão. A qualificação Organizações Sociais ainda, poderá ser concedida pelo Poder Executivo Federal às pessoas jurídicas de direito privado, sem fins lucrativos, que atuem na área do ensino, da pesquisa científica, do desenvolvimento tecnológico, da proteção e preservação do meio ambiente, da cultura e da saúde [21].

Quando se fala em movimentos sociais, logo se relaciona o assunto ao contrato de gestão, mas importante ressaltar que as organizações sociais não devem ser vistas e entendidas como um tipo de entidade pública não estatal, mas uma qualidade dessas entidades, declaradas pelo Estado.

Paulo Modesto entende que

o Estado apenas regulador é o Estado mínimo, mas defende que as reformas gerenciais ocorridas no Brasil pregam o Estado regulador e promotor dos serviços sociais básicos e econômicos estratégicos, sem a necessidade de que sejam realizados pelo aparato estatal [25].

Ainda para entender o objetivo das Organizações Sociais, cita-se Sérgio de Andréa Ferreira:

[...] fica claro, e que embora não expresso na lei, que o principal objetivo das OS não é, como no caso das OSCIP, as associações civis, mas a absorção de atividades desenvolvidas por órgãos e entidades públicas, com conseqüente extinção destes. E, no sentido do que já foi aqui tratado, que embora fale de publicização, a Lei está, efetivamente, galgando mais um passo na diminuição da estrutura administrativa, por um processo de privatização [21].

\section{Maria Sylvia Zanella Di Pietro ressalta que}

o termo 'publicização' é 'inadequado e infeliz', pois apenas ocorreria a 'publicização' se a atividade fosse deslocada da iniciativa privada para a área governamental, e no caso é o inverso, entendendo que ocorre, na verdade, a desestatização [18].

A Lei $n^{\circ} 9.637 / 98$ acaba por dispor sobre a qualificação de entidades como organizações sociais, a criação do Programa Nacional de Publicização, a extinção dos órgãos e entidades que menciona e a absorção de suas atividades por organiza- 
ções sociais, dessa forma é possível dizer que as organizações sociais são vistas como pessoas jurídicas de direito privado, sem fins lucrativos, que estão voltadas para atividades de proeminente estima social, que independem de autorização do Poder Público, designadas por ação de privados segundo exemplo previsto em lei.

A legislação pertinente não lança muitas luzes acerca de uma definição das Organizações Sociais. Entretanto, pode servir como um bom ponto de partida o art. $1^{\circ}$ da Lei 9.637/98, in verbis:

Art. $1^{\circ} \mathrm{O}$ Poder Executivo poderá qualificar como organizações sociais pessoas jurídicas de direito privado, sem fins lucrativos, cujas atividades sejam dirigidas ao ensino, à pesquisa científica, ao desenvolvimento tecnológico, à proteção e preservação do meio ambiente, à cultura e à saúde, atendidos aos requisitos previstos nesta Lei [13].

O conceito legal revela-se insuficiente para abranger toda a complexidade do instituto. Paulo Eduardo Garrido Modesto, que nos traz uma definição mais analítica em seu trabalho Reforma Administrativa e do Marco Legal das Organizações Sociais no Brasil - As Dúvidas dos Juristas sobre o Modelo das Organizações Sociais, a saber:

As organizações sociais são pessoas jurídicas de direito privado, sem fins lucrativos, voltadas para atividades de relevante valor social, que independem de concessão ou permissão do Poder Executivo, criadas por iniciativas de particulares segundo modelo previsto em lei, reconhecidas, fiscalizadas e fomentadas pelo Estado.

Entende-se dos estudos sobre as Organizações Sociais que a presente definição merece alguns apontamentos, no que se refere à ideia de que se trata de um título jurídico, uma qualificação especial de uma entidade sem fins lucrativos, que atendam às exigências especiais previstas em lei; bem como que a noção de que deve atuar nos serviços públicos não exclusivos do Estado e ainda deve-se entender que a ideia do Contrato de Gestão, que consubstancia o liame necessário à vinculação entre a organização e o Estado, revelando-se como parte integrante da sua própria essência. Tais apontamentos parecem esquecidos em algumas definições sobre as Organizações Sociais, cabendo nesse momento ressaltar suas ausências e chamar a atenção para novas analises de conceitos.

Apesar de todas as insuficiências e excessos do arcabouço normativo das Organizações Sociais, não há que se tomar uma atitude iconoclasta e fechar os olhos para alguns aspectos positivos do novo regramento legal. Em muitos pontos, a qualificação em estudo supera o antigo título de utilidade Pública, como o caso de se especificar, os estatutos das Organizações Sociais que devem, nos temos do art. $3^{\circ}$ da Lei 9637/98 [13], satisfazer a certos requisitos no tocante ao modelo de composição para seus órgãos de deliberação superior. Prevê-se a necessária participação de representantes do Estado e da Sociedade Civil, até como forma de compensar a extrema liberdade, em relação ao regime jurídico de Direito Púbico, dispensado às Organizações Sociais. Na outra mão, continuando fortemente o Estado presente na estrutura diretiva da Organização, vem apenas a gerar mais uma forte evidência do movimento de fuga da Administração às amarras do regime jurídico de Direito Público.

Outro avanço pode ser identificado na figura do contrato de gestão, que, abstraídas as questões terminológicas e técnicas, que são de muita valia e importância, conferindo limites e definindo metas a serem atingidas pela entidade, o que pode ser relevante no controle da aplicação dos recursos públicos na finalidade a si atribuída. Ainda no campo do controle, a Lei exige, para a própria qualificação, que o estatuto da entidade qualificada preveja uma sujeição à publicação anual, no Diário Oficial da União, do relatório de execução do contrato de gestão, enquanto um relatório gerencial das atividades desenvolvidas, e não um mero demonstrativo de contabilidade formal, como era comum nas Entidades de Utilidade Pública.

De tudo isso, verifica-se uma tentativa de efetivar controles que contrabalancem as facilidades abertas pela flexibilização lograda com as Organizações Sociais. A partir da avaliação dos benefícios e prejuízos deste modelo, pode-se refletir e, com a experiência adquirida, desde as primeiras incursões legislativas nessa área, seguir rumo ao modelo ideal.

Diante de todo esse entendimento sobre as organizações sociais, é possível ainda chamar atenção para as associações e as fundações que podem ser qualificadas como organizações sociais, mas as sociedades não podem ser consideradas por terem desígnio lucrativo. No entanto, a Lei decide como condição para a designação como organização social que a entidade tenha um conselho de administração ${ }^{2}$ como órgão de deliberação o qual deve apresentar representantes do Poder Público.

Destaca-se ainda que poucas organizações sociais foram constituídas, o que acabou ocasionando a indigência da criação das organizações da sociedade civil de interesse público, com uma legislação mais simples.

Após todo esse embasamento conceitual e histórico, podese afirmar que em meio a todo o processo de maturação, bem como os avanços e flexibilizações, foram criadas as OSCIPs, sendo regulamentadas pelo Decreto 3100/99 [15]. No entanto, as entidades do terceiro setor, vieram a incorporar boa parte das inovações trazidas pela Lei das Organizações Sociais, naquilo que elas tinham de avanço. E assim, muitas são as semelhanças entre as OSCIPs e as OS. Entretanto, ainda há falhas, que deverão ser corrigidas com o transcurso do tempo. Uma delas é que a lei 9790/99 (Lei das OSCIPS), não prevê um tempo máximo de duração do mandato dos dirigentes das entidades, bem como não estabelece critérios rígidos para desqualificar a entidade caso a mesma seja condenada por atos de improbidade.

Com o propósito de superar algumas das insuficiências da disciplina normativa das Organizações Sociais, a Lei das

\footnotetext{
${ }^{2}$ Os conselheiros não devem receber remuneração pelos serviços, podendo apenas receber ajuda de custo por reunião que participem.
} 
OSCIPs (Lei 9790/99) trouxe uma série de mudanças, que contribuiu para conferir ao novo título uma credibilidade muito maior. Entre as principais destaque-se a enunciação taxativa, no art. $2^{\circ}$, daqueles que não podem qualificar-se como OSCIP, ainda que se dediquem a atividade tutelada pelas normas pertinentes a tais organizações. Em boa hora tais restrições, pois vem a assegurar que os benefícios gerados pela sua atuação atinjam a todos, numa excelente definição para aquilo que outrora se chamou de "servir desinteressadamente à coletividade". Estão excluídos, por exemplo, sociedades comerciais, partidos políticos, escolas privadas e instituições hospitalares não gratuitos, dentre outras [17].

Da mesma forma, o art. $3^{\circ}$ vem enumerar e detalhar as atividades a que se devem dedicar as instituições, a fim de que possam se credenciar como OSCIP, o que demonstra uma preocupação e uma rigidez muito maior na qualificação, o que se justifica pelo fato de ter a certificação de OSCIP um caráter vinculado, não afeito ao mero juízo de conveniência e oportunidade do administrados, o que vem a superar uma velha reivindicação do terceiro setor, qual seja, a eliminação de um moroso trâmite burocrático para a obtenção do título. Isto é depreendido dos termos do art. $6^{\circ}, \S 3^{\circ}$, da lei em tela ("O pedido de qualificação somente será indeferido quando:”). $\mathrm{O}$ prazo para o deferimento ou indeferimento do pedido será de trinta dias, e, no caso de deferimento, o Ministério da Justiça terá quinze dias para expedir o certificado de qualificação. ( $\S 1^{\circ}$ e $2^{\circ}$ do mesmo artigo).

Contudo, não há só elogios à normatização das OSCIPs. Ainda há algumas insuficiências e contradições, que no decorrer do presente estudo serão abordadas.

Em continuidade ao estudo do Estado e da Administração, far-se-á no próximo capítulo a análise de alguns conceitos e as relações da Sociedade Civil e o Terceiro Setor.

\section{A RELAÇÃO DA SOCIEDADE CIVIL E O TERCEIRO SETOR}

\section{A. ORIGENS, DEFINIÇÕES E ENQUADRAMENTO NO ORDENAMENTO JURÍDICO}

O estudo doutrinário permite uma variedade de definições do chamado terceiro setor ${ }^{3}$, as quais elevam as discussões a respeito das composições e a própria questão terminológica.

Trabalha-se ainda as funções, a mudança do Estado no pagamento das prestações sociais e ações diretamente vinculadas ao sistema jurídico. Para tanto é ressalta-se a doutrina de José Eduardo Sabo Paes, que salienta:

[...] o conjunto de organismos, organizações ou instituições dotados de autonomia e administração própria que apresentam como função e objetivo principal atuar voluntariamente junto à sociedade civil visando ao seu aperfeiçoamento [28].

Destaca-se que a opinião de grande parte dos doutrinadores,25 acompanha uma linha de exclusão, pois, na nossa

\footnotetext{
${ }^{3}$ Ressalta-se que os pesquisadores devem tomar cuidado para não criar qualquer comparativo de semelhança do Terceiro Setor, com setor terciário na economia, que são as atividades de serviços, ao contrário dos setores primário (agricultura) e secundário (indústria).
}

sociedade atual é possível apontar e perfilhar o que seja uma atividade governamental, e o que apenas destaque interesse privado mediado pelo Estado.26 Sendo assim, destaca-se pequeno trecho do livro Terceiro setor e suas perspectivas:

[...] um autêntico terceiro pilar compreendendo as atividades espontâneas, não governamentais e não lucrativas, de interesse público, realizadas em benefício geral da sociedade, não apenas dos indivíduos em particular; e que desenvolvem independentemente dos demais setores, ainda que deles possa(para alguns, até, deva) receber colaboração.

Quando se consideram as questões de afirmação histórica do presente assunto, presencia-se que conceituar é realmente difícil, pois cada doutrinador segue uma linha específica de entendimento. Determinados autores dão maior enfoque ao Estado e as questões sociais, outros priorizam o direito das pessoas, suas capacidades e incapacidades, e sem sombras de dúvidas a grande maioria estabelece os diferenciais da dicotomia pública e privada, como bem salienta Leandro Marins de Souza,

o Terceiro setor é toda ação, sem intuito lucrativo, praticado por pessoa física ou jurídica de natureza privada, como expressão da participação popular, que tenha por finalidade a promoção de um direito social ou seus princípios [32].

Para Boaventura de Souza Santos o terceiro setor é bem visto com seu vastíssimo ambiente de organizações sociais, a saber:

uma designação residual e vaga com que se pretende dar conta de um vastíssimo conjunto de organizações sociais que não são nem estatais nem mercantis", "privadas", que "não visam fins lucrativos", e são "animadas por objetivos sociais, públicos ou coletivos [8].

Ou ainda na opinião de Gustavo Henrique Justino de Oliveira,

é o conjunto de atividades voluntárias desenvolvidas por organizações privadas não-governamentais e sem ânimo de lucro (associações e fundações), realizadas em prol da sociedade, independentemente dos demais setores (Estado e mercado), embora deles possa firmar parcerias e receber investimentos (públicos e privados) [26].

A partir da análise dos conceitos é possível dizer que o terceiro setor é visto como sendo um conjunto de organismos ou instituições sem fins lucrativos dotados de autonomia. Grandes partes das estatísticas hoje realizadas apresentam o contraditório dos números no que se refere à quantidade de entidades do terceiro setor no Brasil, e no que se refere às qualificações.

De um modo geral associa-se o Terceiro Setor as instituições sem fins lucrativos das quais são desenvolvidas atividades para o bem comum. No entanto, é interessante ressaltar que quando se levanta uma especifica análise a respeito das instituições sem fins lucrativos, logo se diz ${ }^{4}$ que

\footnotetext{
${ }^{4}$ Dados retirados do IBGE
} 
são instituições que estão fora dos andamentos normais da legislação brasileira, mas que são utilizadas para andamentos de pesquisas e até mesmo para prestar devidas orientações no âmbito internacional. Logo, o nosso país acaba por adotar praticamente tais instituições. Deve-se sempre levar em consideração que no Brasil, a atenção maior sempre foi voltada ao "Primeiro Setor" que representa o governo, cumprir este uma função administrativa dos bens públicos, corresponderem assim às ações do Estado com fins públicos, tanto no âmbito municipal, estadual como federal, bem como o Segundo Setor ${ }^{5}$, representado pelo mercado, ocupado pelas empresas privadas com fins lucrativos.

Diante do surgimento e desenvolvimento do Segundo Setor, tanto o Estado quanto o mercado ocupado pelas empresas privadas com fins lucrativos, começaram a valorizar a partir da década de 90 os movimentos voltados aos projetos sociais, conjuntamente o mercado inicia uma nova preocupação a de não estar apto a responder aos desafios do desenvolvimento com igualdade. Para melhor exemplificar segue a citação abaixo de Rubens C. Fernandes:

A participação dos cidadãos é essencial para consolidar a democracia e uma sociedade civil dinâmica é o melhor instrumento de que dispomos para reverter o quadro de pobreza, violência e exclusão social que ameaça os fundamentos de nossa vida em comum [19].

E ainda, complementa que

[...] um conjunto de organizações e iniciativas privadas que visam à produção de bens e serviços públicos. Este é o sentido positivo da expressão. 'Bens e serviços públicos', nesse caso implicam uma dupla qualificação: não geram lucros e respondem a necessidades coletivas.

Dessa forma, fica fácil entender que o Terceiro Setor é a nova fase direcionada às iniciativas privadas, que de um modo geral não visam lucros, bem como iniciativas no âmbito público que não são manifestadas por um Estado, deixando certa a participação de pessoas, cidadãos de uma forma liberada, espontânea e voluntária, mas sempre com intuito de coletividade de direitos ${ }^{6}$.

Para melhor exemplificar o que até o presente momento foi dito, destaca-se que

a designação 'Terceiro Setor' identifica área pertinente

e implicada com a solução das questões sociais: - o

Primeiro Setor é o Governo, representante do Estado

e maior provedor das necessidades de uma coletivi-

dade. No segundo Setor encontra-se a iniciativa pri-

vada, cuja competência administrativa dos meios de

produção cuida da satisfação dos anseios individuais.

Com o aumento das carências e ameaças de falência do

Estado, a mesma iniciativa privada (cidadania) passou a

\footnotetext{
${ }^{5}$ Deve-se considerar que mesmo no caso de análise do Segundo Setor, é necessário visualizar que o mesmo funciona com uma lógica diferente, visando sempre o lucro, bem como destaca-se que a partir da década de 90 é que os movimentos em função de projetos sociais foi iniciado. Dando assim, oportunidade para o aparecimento do "terceiro setor".

${ }^{6}$ É o de que se trata de uma esfera de atuação pública, não estatal, formada a partir de iniciativas voluntárias, sem fins lucrativos, no sentido comum [22]
}

se preocupar com questões sociais. Deste último extrato, surge o 'Terceiro Setor', representado por cidadãos integrados em organizações sem fins lucrativos, nãogovernamentais, voltados para a solução de problemas sociais e com objetivo final de gerar serviços de caráter público [31].

Logo, o Terceiro Setor e o Estado, apresentam semelhanças, pois, ambos devem desempenhar uma função de modo eminente para a coletividade, bem como da definição acima transcrita é possível entender que as atitudes privadas, fazem a distinção da Sociedade Civil e do Estado, mais também fica claro que o Terceiro Setor pode sofrer influências estatais, como confirmação destaca-se que,

neste contexto, pode-se afirmar que a Sociedade Civil distingue-se do Estado, mas ao se motivar pela promoção dos interesses coletivos, também se distancia da lógica de mercado. Tal condição, característica do Terceiro Setor, induz a conhecidos conceitos segundo os quais ser não-governamental e sem fins lucrativos não traz imunidade às influências estatais ou a condicionamentos sociais.

No entanto é interessante falar que alguns teóricos consideram o termo Terceiro Setor, como a sociedade civil, mais para ser possível tal entendimento se faz necessário antes entender a afirmação histórica do Terceiro Setor, bem como seu agrupamento que inicialmente pode-se afirmar vem a ser formado por: Organizações Não Governamentais, Fundações e Institutos Empresariais, Associações Comunitárias, Entidades Assistenciais e Filantrópicas, assim como várias outras instituições sem fins lucrativos. Como será analisado no item a seguir.

\section{1) Breve consideração histórica do Terceiro Setor}

A afirmação histórica do Terceiro Setor se dá a partir do século XIX, no qual a presença das instituições religiosas vinculava a maior parte do Estado, tanto porque naquela época a atuação da igreja era o atual papel do Terceiro Setor ${ }^{7}$, ou seja, a prestação de serviços de assistência à comunidade.

Por volta do século XX, outras filantropias se associam ao Estado e criam o seu auge durante o período Republicano. Logo, a Igreja e o Estado estabelecem total companhia e com isso nasce uma mudança de paradigma Estatal, antes não vivenciada, permitindo que a sociedade apresentasse forças modernistas e desse inicio ao novo período chamado de industrialização e urbanização, aumentando é claro as pressões sociais e dificultando as resoluções dos problemas dentro da sociedade moderna.

Aproximadamente entre as décadas de setenta e oitenta, a nação vive movimentos sociais que manifestam indigna-

\footnotetext{
${ }^{7}$ Entretanto, discute-se também se realmente o Estado seria o primeiro setor, o mercado o segundo setor e sociedade civil o "terceiro setor". A professora Simone de Castro Tavares Coelho informa que o termo "terceiro setor" (third sector) foi utilizado pela primeira vez por pesquisadores nos Estados Unidos na década de 70, e a partir da década de 80 por pesquisadores europeus, mais que dúvidas a respeito do terceiro setor, ser realmente o terceiro setor ainda existem.
} 
ções principalmente no campo das práticas autoritárias do regime militar, assim como reivindicando direitos sociais. É claro que não se pode esquecer da atuação magnífica de surgimento e mobilização da Constituição da República Federativa Brasileira em 1988, que destacou direitos antes nunca ressaltados, e eleva principalmente os direitos e garantias fundamentais do indivíduo, mais da mesma forma, eleva também movimentos de classes, para emanar emendas constitucionais.

Nas palavras de Fernando Henrique Cardoso [33]:

Nós temos que entender que o mundo moderno não existe apenas Estado e empresa, existem trabalhadores organizados, sindicatos e existe uma imensa massa não organizada, e existem muitas formas de organização que não são nem sindicato, nem empresa, nem burocracia estatal. Tudo isso tem que ser mobilizado em conjunto... Nos alvores do novo milênio nós estamos assistindo à formação de novos tipos de sociedade que não estão baseados, apenas, na oposição entre setores privados organizados, trabalhadores e empresários, nem desses com o Estado.

[...] Nós estamos assistindo à formação do que se costuma chamar terceiro setor: formas de associação, formas de sociabilidade que não se restringem à dicotomia básica clássica entre Estado e sociedade civil, à antiga. É a sociedade civil à moderna, ou seja, não contando apenas os setores produtores da sociedade civil. São novas formas de sociabilidade.

[...] O que há de novo...é que existem formas dinâmicas de controle social, de organização de objetivos, e até mesmo de generosidade e de solidariedade, que não decorrem nem do princípio racionalizador do mercado, nem do princípio autoritário de distribuição do Estado. E que são energias novas, que são cada vez mais incorporadas à fisionomia das sociedades contemporâneas. É disso que se trata, é de organizar, criar instrumentos e arenas que possibilitem de uma maneira mais adequada a canalização dessas energias novas da sociedade [...].

Nas últimas décadas o destaque encontra-se com as Organizações Não Governamentais (ONGs). Com a materialização democrática, por intermédio das pluralidades partidárias, concepção de sindicatos e fortalecimentos de movimentos sociais urbanos e rurais, abre-se lugar para uma performance mais efetiva das ONGs ${ }^{8}$.

\section{CONSIDERAÇÕES FINAIS}

Diante de todo o exposto no presente artigo, pode-se concluir realmente que o mundo não é possível imaginar o mundo de hoje, com a população atual, sem a atuação do chamado Terceiro Setor. Infelizmente, o aumento populacional desenfreado e sem qualquer planejamento, fez com que uma demanda fosse gerada em todas as aéreas(saúde, educação, assistência

${ }^{8}$ No entanto, cabe ressaltar que a falta de atitude do Estado, contribuiu para o crescimento e expansão de Terceiro Setor, que sempre objetiva as necessidades da população menos favorecida, em vários sentidos. social e outras).E, com certeza, tal demanda precisa ser suprida através de algum mecanismo. Nesse ponto, tem-se o papel das ONGS, O.S, OSCIPS e outras entidades que foram constituídas para esse fim. Através delas, podemos observar a evolução das camadas menos favorecidas e o consequente fortalecimento do Estado, pois através dos convênios, termos de

40 No entanto, cabe ressaltar que a falta de atitude do Estado, contribuiu para o crescimento e expansão de Terceiro Setor, que sempre objetiva as necessidades da população menos favorecida, em vários sentidos.

parceria e contratos com essas instituições, repassam recursos, desburocratizam o sistema e suprem a demanda da população. Entretanto, nem tudo é perfeito como na teoria. Ainda existe uma grande parte de instituições que buscam recursos públicos e infelizmente por conta de negociações políticas ficam fora dos beneficiados e acabam não podendo executar da melhor maneira seu papel, fundamental para a população em geral. Além disso, falta ainda por parte do poder público, uma maior fiscalização e repressão à algumas instituições do Terceiro Setor que recebem valores astronômicos do poder público e nada fazem em benefício da Sociedade. Nos Estados Unidos por exemplo há um controle rígido das verbas com prestações de contas detalhadas e repressão a todas as irregularidades encontradas. Aos poucos, os países menos desenvolvidos vão evoluindo nesse sentido, até que cheguem a patamares de controle e desenvolvimento adequados para que o Terceiro Setor seja realmente ferramenta de transformação social e econômica nos países que realmente necessitam.

\section{Referências}

[1] BACELLAR FILHO, Romeu Felipe. Reflexões do direito administrativo. São Paulo: Fórum, 2010.

[2] BARRA, Rodolfo. Fuentes del ordenamiento de la integración. Buenos Aires: Ábaco, 1998.

[3] BAVA, Silvio C. O terceiro setor e os desafios do estado de São Paulo para o século XXI. São Paulo: Autores Associados, 2008.

[4] BOBBIO, Norberto. Le fonti del diritto in Kelsen. In: BOBBIO, Norberto. Diritto e potere. Napoli: Scientifiche Italiane, 1992.

[5] BOBBIO, Norberto. Estado, governo, sociedade: para uma teoria geral da política. 13. ed. São Paulo: Paz e Terra, 2006.

[6] BODIN, Jean. Los seis libros de la república. Madrid: Tecnos, 1997. BONAVIDES, Paulo. Do estado liberal ao estado social. 7. ed. São Paulo: Malheiros, 2006

[7] BRASIL. Lei $n^{\circ} 4.320$, de 17 de março de 1964. Estatui Normas Gerais de Direito Financeiro para elaboração e controle dos orçamentos e balanços da União, dos Estados, dos Municípios e do Distrito Federal. Diário Oficial da União, 23 mar. 1964

[8] BRASIL. Lei $n^{\circ} 5.764$, de 16 de dezembro de 1971. Define a Política Nacional de Cooperativismo, institui o regime jurídico das sociedades cooperativas, e dá outras providências. Diário Oficial da União, Brasília, DF, 16 dez. 1971.

[9] BRASIL. Decreto $n^{\circ} 93.872$, de 23 de dezembro de 1986. Dispõe sobre a unificação dos recursos de caixa do Tesouro Nacional, atualiza e consolida a legislação pertinente e dá outras providências. Diário Oficial da União, Brasília, DF, 24 dez. 1986.

[10] BRASIL. Lei $\mathrm{n}^{\circ} 8.742$, de 7 de dezembro de 1993. Dispõe Sobre a Organização da Assistência Social e dá outras providências. Diário Oficial da União, Brasília, DF, 8 dez. 1993.

[11] BRASIL. Lei $n^{\circ} 9.637$, de 15 de maio de 1998. Dispõe sobre a qualificação de entidades como organizações sociais, a criação do Programa Nacional de Publicização, a extinção dos órgãos e entidades que menciona e a absor- 
ção de suas atividades por organizações sociais, e dá outras providências. Diário Oficial da União, Brasília, DF, 18 maio 1998.

[12] BRASIL. Lei $n^{\circ} 9.790$, de 23 de março de 1999. Dispõe sobre a qualificação de pessoas jurídicas de direito privado, sem fins lucrativos, como Organizações da Sociedade Civil de Interesse Público, institui e disciplina o Termo de Parceria, e dá outras providências. Diário Oficial da União, Brasília, DF, 24 mar. 1999a.

[13] BRASIL. Decreto $n^{\circ} 3.100$, de 30 de junho de 1999. Regulamenta a Lei ${ }^{\circ}$ 9.790 , de 23 de março de 1999, que dispõe sobre a qualificação de pessoas jurídicas de direito privado, sem fins lucrativos, como Organizações da Sociedade Civil de Interesse Público, institui e disciplina o Termo de Parceria, e dá outras providências. Diário Oficial da União, Brasília, DF, 1 jul. 1999 b.

[14] BRASIL. Lei $n^{\circ} 9.867$, de 10 de novembro de 1999. Dispõe sobre a criação e o funcionamento de Cooperativas Sociais, visando à integração social dos cidadãos, conforme especifica. Diário Oficial da União, Brasília, DF, 11 nov. $1999 \mathrm{c}$.

[15] BRASIL. Lei $\mathrm{n}^{\circ} 11.178$, de 20 de setembro de 2005. Dispõe sobre as diretrizes para a elaboração da Lei Orçamentária de 2006 e dá outras providências. Diário Oficial da União, Brasília, DF, 21 set. 2005.

[16] BRASIL. Código civil brasileiro. São Paulo: Saraiva, 2010a.

[17] BRASIL. Constituição da República Federativa Brasileira. São Paulo: Saraiva, 2010b.

[18] DI PIETRO, Maria Sylvia Zanella. Curso de direito administrativo. Curitiba: Atlas, 2007.

[19] FERNANDES, Rubem César. Privado, porém público: o terceiro setor na América Latina. Rio de Janeiro: Relume-Dumará, 1994.

[20] FERNANDES, Rubem César. 2. ed. Rio de Janeiro: Relume-Dumará, 1997.

[21] FERREIRA, Sérgio de Andréa. Lições de direito administrativo. Rio de Janeiro: Rio, 1962

[22] GONÇALVES, Vania Mara Nascimento. Estado, sociedade civil e princípio da subsidiariedade na era da globalização. Rio de Janeiro: Renovar, 2006.

[23] MEIRELLES, Hely Lopes. Direito administrativo. São Paulo: Malheiros, 2009 .

[24] MODESTO, Paulo Eduardo Garrido. Nova organização administrativa brasileira. Belo Horizonte: Fórum, 2008a.

[25] MODESTO, Paulo Eduardo Garrido.Reforma administrativa e do marco legal das organizações sociais no Brasil: as dúvidas dos juristas sobre o modelo das organizações sociais. Belo Horizonte: Fórum, 2008b.

[26] OLIVEIRA, Gustavo Henrique Justino de; MÂNICA, Fernando Borges. Organizações da sociedade civil de interesse público: termo de parceria e licitação. Fórum Administrativo - Direito Público, Belo Horizonte, ano 5, n. 49, mar. 2005.

[27] PAES, José Eduardo Sabo. Fundações e entidades de interesse social: aspectos jurídicos, administrativos, contábeis e tributários. 3. ed. Brasília: Brasília Jurídica, 2001.

[28] PAES, José Eduardo Sabo. Terceiro setor: conceituação e observância dos princípios constitucionais aplicáveis à administração pública. Fórum Administrativo - Direito Público, Belo Horizonte, ano 5, n. 48, fev. 2005.

[29] REALE, Miguel. Teoria do direito e do estado. 5. ed. São Paulo: Saraiva, 2000.

[30] ROUSSEAU, Jean-Jacques. Do contrato social ou princípios do direito político. Tradução Pietro Nassetti. São Paulo: Martin Claret, 2006

[31] SÃO PAULO. Tribunal de Contas do Estado de São Paulo. Manual básico: repasses públicos ao Terceiro Setor. São Paulo: Tribunal de Contas, 2004.

[32] SOUZA, Leandro Marins de. Tributação do terceiro setor no Brasil. São Paulo: Dialética, 2004.

[33] CARDOSO, Fernando Henrique. Discurso na cerimônia de sanção da Lei do Voluntariado apud FRANCO, Augusto de. A reforma do estado e o terceiro setor. In: PEREIRA, Luiz Carlos Bresser; WILHEIM, Jorge; SOLA, Lourdes (Orgs.). Sociedade e estado em transformação. São Paulo: Unesp, 2001. p. 10.
BRUNO VALVERDE CHAHAIRA

Doutorado em Função Social do Direito pela Faculdade Autônoma de Direito, Brasil(2016). Advocacia do Ordem dos Advogados do Brasil, Brasil. 